www.parjournal.net

\title{
Current applications of propeller flaps in reconstruction of trunk wounds
}

\author{
Shawn Moshrefi, Gordon K. Lee \\ Division of Plastic \& Reconstructive Surgery, Stanford University Medical Center, Palo Alto, CA 94305, USA.
}

Correspondence to: Dr. Shawn Moshrefi, Division of Plastic \& Reconstructive Surgery, Stanford University Medical Center, Palo Alto, CA 94305, USA. E-mail: moshrefi@stanford.edu; Dr. Gordon K. Lee, Division of Plastic \& Reconstructive Surgery, Stanford University Medical Center, Palo Alto, CA 94305, USA. E-mail: glee@stanford.edu

How to cite this article: Moshrefi S, Lee GK. Current applications of propeller flaps in reconstruction of trunk wounds. Plast Aesthet Res 2017;4:204-8.

\section{Article history: \\ Received: 29 Apr 2017 \\ First Decision: 16 Oct 2017 \\ Revised: 27 Nov 2017 \\ Accepted: 27 Nov 2017 \\ Published: 30 Nov 2017}

Key words:

Propeller flaps,

trunk wounds,

microvascular dissection

\section{INTRODUCTION}

The concept of the perforator flap was first introduced in 1988 by Kroll and Rosenfield ${ }^{[1]}$ as

\begin{abstract}
Aim: Propeller flaps provide excellent reconstructive options for defects of many etiologies. Trunk wounds are a commonly encountered issue for the plastic surgeon and multiple techniques to address them should be prepared for implementation. Propeller flaps are a subject rarely brought up as an option to address these wounds. The authors sought to elucidate this topic in the current plastic surgery literature available. Methods: A PubMed search was conducted based upon the defined inclusion and exclusion criteria and publications reviewed in detail. Search terms included "trunk wound propeller flap", "trunk propeller flap", and "freestyle trunk wound flap". Duplicate studies were excluded. Data was extracted from each study pertaining to trunk wounds and reconstructions with propeller flaps. Results: The electronic search yielded 49 results with 21 studies ultimately meeting inclusion criteria. A total of 365 flaps were described collectively amongst the included studies. Among them, 190 propeller flaps addressing trunk defects were performed across all studies reviewed to address a total of 165 defects of the trunk: 14 abdomen, 101 back, 50 chest defects and adjacent respective flaps were utilized for surgical reconstruction. Overall, cancer excision wounds were by far the most prevalent with 105 cases (59.0\%). Defect sizes of those specified in the articles ranged from $2 \mathrm{~cm} \times 5 \mathrm{~cm}$ to $30 \mathrm{~cm} \times 24 \mathrm{~cm}$. Of the 190 propeller flaps identified, 63 total complications were identified. The most common complication was 48 total cases of transient venous congestion (25.3\%). The second most common complication was partial flap necrosis $(6.3 \%)$. No total flap loss was noted. There were 2 cases of seroma (1.1\%) and 1 case of wound breakdown $(0.5 \%)$. Conclusion: Propeller flaps are a viable reconstructive option for trunk wounds and should be in the armamentarium of plastic and reconstructive surgeons. Few studies are available in the literature regarding propeller flap reconstruction in trunk wounds. More aggregate data is needed in order to further review, evaluate, and refine propeller flap techniques and results.
\end{abstract}

well as independent work introduced in 1989 by Koshima and Soeda ${ }^{[2]}$. Since then, the concept of perforator flaps and propeller flaps has flourished both in theory, innovation, and clinical application.

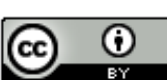

This is an open access article licensed under the terms of Creative Commons Attribution 4.0 International License (https://creativecommons.org/licenses/by/4.0/), which permits unrestricted use, distribution, and reproduction in any medium, as long as the original author is credited and the new creations are licensed under the identical terms.
}

For reprints contact: service@oaepublish.com

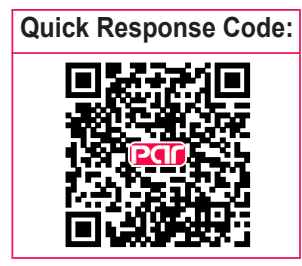


As is true of most plastic surgery, the propeller flap can be utilized in essentially any part of the body so long as plastic surgical principles are adhered to and meticulous surgical attention is directed toward flap design, dissection, and ultimately to reconstruction. While clinical application is broad, the focus of this article is in review of propeller flaps for trunk wound reconstruction.

\section{METHODS}

A PubMed Booleansearch was conducted searching for the terms "trunk wound propeller flap", "trunk propeller flap", and "freestyle trunk wound flap". The results of this search were compiled and duplicates excluded. The remaining publications were vetted based on the inclusion and exclusion criteria noted below. The publications were then reviewed in detail.

Inclusion criteria for this study were that the studies be a case study, case report, case series, clinical trial, reply to another study with new patient data, cohort analysis, or other retrospective or prospective studies identifying trunk wounds as the reconstructive defect. Additionally, a propeller flap had to be utilized for surgical reconstruction. Exclusion criteria for the study were that the publication was not entirely in the English language, publication not reproducibly accessed, paper did not provide enough detail regarding surgical intervention to determine if propeller flap technique was utilized, pedicled perforator flaps were not utilized in propeller fashion, or that the paper was primarily a review of the literature.

\section{RESULTS}

The results of the PubMed online search yielded 49 publications. After excluding duplicates, 35 publications remained. These 35 were reviewed in detail and the publications vetted based on the inclusion and exclusion criteria noted above. Twentyonearticles remained for further in-depth review.

Of these 21 articles, 13 articles were case series, 8 articles were case studies/reports, and no clinical trials or cohort studies were identified. The oldest article found in the search dated back to August 2009.

A total of 365 flaps were described collectively amongst the included studies. Among them, 190 propeller flaps addressing trunk defects were performed across all studies reviewed to address a total of 165 defects of the trunk: 14 abdomen, 101 back, 50 chest defects and adjacent respective flaps were utilized for surgical reconstruction. The discrepancy between the total number of flaps utilized and the total number of defects was that in some cases more than one propeller flap was utilized for reconstruction of a site.

Etiologies of the defects addressed resulted from burns, wounds, pressure sores, hidradenitis suppuritiva, hardware exposures, keloids and/or scars, myelomeningoceles, pseudomeningoceles, pilonidal disease, radiation wounds, and cancers of various types. One case had an unspecified cause of the defect. Overall, cancer excision wounds were by far the most prevalent with 105 cases (59.0\%). Defect sizes of those specified in the articles ranged from $2 \mathrm{~cm} \times 5 \mathrm{~cm}$ to $30 \mathrm{~cm} \times 24 \mathrm{~cm}$. Please see Table $1^{[3-23]}$ for the breakdown of each etiology related to each defect for each included study in the review.

Perforators for the flaps were identified most commonly by handheld Doppler ultrasound. Other methods of perforator identification included color Doppler ultrasonography (CDU), combined laser Doppler spectrophotometry, computed tomography angiography (CTA), and dissection with visual identification and palpation. Some studies did not specify the method of perforator identification. Of the studies that specified flap dimensions, the propeller flaps ranged from $4 \mathrm{~cm} \times 6 \mathrm{~cm}$ to $30 \mathrm{~cm} \times 17 \mathrm{~cm}$.

Of the 190 propeller flaps identified, 63 total complications were identified. The most common complication was 48 total cases of transient venous congestion (25.3\%). The second most common complication was partial flap necrosis (6.3\%). No total flap loss was noted. There were 2 cases of seroma $(1.1 \%)$ and 1 case of wound breakdown (0.5\%).

\section{DISCUSSION}

The propeller flap concept and technique has continued to evolve in idea and application. The benefits of utilizing a propeller flap include locoregional reconstruction, reliable anatomy based upon the angiosome and perforasome concepts ${ }^{[24]}$, minimization of donor site morbidity, and design that is largely limited only by ability to close primarily.

The evolution of the propeller flap has included multiple modifications both in application and technique. Papers indicating flap degrees of rotation less than 180 degrees were described and utilized successfully. Some series utilized this as a workhorse in propeller flap reconstruction for trunk wounds.

Reviewing the data from the series, it is interesting 
Table 1: Aggregate results of all papers included in study

\begin{tabular}{|c|c|c|c|c|c|c|c|c|c|c|}
\hline & $\begin{array}{c}\text { Total } \\
\text { No. } \\
\text { of } \\
\text { flaps }\end{array}$ & $\begin{array}{l}\text { No. of } \\
\text { flaps } \\
\text { meeting } \\
\text { study } \\
\text { criteria }\end{array}$ & $\begin{array}{l}\text { Location of } \\
\text { defect }\end{array}$ & $\begin{array}{c}\text { Defect } \\
\text { dimensions }\end{array}$ & $\begin{array}{l}\text { Etiology } \\
\text { of defect }\end{array}$ & $\begin{array}{l}\text { Method of } \\
\text { perforator } \\
\text { identifi- } \\
\text { cation }\end{array}$ & $\begin{array}{c}\text { Flap } \\
\text { dimensions }\end{array}$ & $\begin{array}{c}\text { Donor site } \\
\text { closure }\end{array}$ & $\begin{array}{c}\text { Patient } \\
\text { risk } \\
\text { factors }\end{array}$ & $\begin{array}{l}\text { Flap } \\
\text { compli- } \\
\text { cations }\end{array}$ \\
\hline $\begin{array}{l}\text { Brunetti } \\
\text { et al. }{ }^{[3]}\end{array}$ & 40 & 20 & $\begin{array}{l}9 \text { back, } \\
11 \text { chest }\end{array}$ & $\begin{array}{c}5 \mathrm{~cm} \times 4 \mathrm{~cm} \text { to } \\
13 \mathrm{~cm} \times \\
9 \mathrm{~cm}\end{array}$ & $\begin{array}{c}15 \text { cancer, } \\
2 \mathrm{HS}, \\
3 \mathrm{PS}\end{array}$ & Doppler & $\begin{array}{l}10 \mathrm{~cm} \times 4 \mathrm{~cm} \text { to } \\
21 \mathrm{~cm} \times 10 \mathrm{~cm}\end{array}$ & $\begin{array}{c}20(100 \%) \text { primary } \\
\text { closure }\end{array}$ & $\begin{array}{l}10 \text { smokers, } \\
3 \text { RT }\end{array}$ & $\begin{array}{l}3(15 \%) \\
\text { partial flap } \\
\text { necrosis }\end{array}$ \\
\hline Zang et al. ${ }^{[4]}$ & 1 & 1 & 1 chest & $13 \mathrm{~cm} \times 6 \mathrm{~cm}$ & $1 \mathrm{RT}$ & Doppler & $15 \mathrm{~cm} \times 6 \mathrm{~cm}$ & Skin graft & $1 \mathrm{RT}$ & None \\
\hline Moon et al. ${ }^{[5]}$ & 13 & 13 & 13 back & $\begin{array}{c}2 \mathrm{~cm} \times 5 \mathrm{~cm} \\
\text { and } 8 \mathrm{~cm} \times \\
8 \mathrm{~cm}, 11 \mathrm{cases} \\
\text { unspecified }\end{array}$ & $\begin{array}{l}2 \mathrm{HE}, \\
2 \mathrm{PM}, \\
9 \mathrm{PS}\end{array}$ & CTA & $\begin{array}{c}5 \mathrm{~cm} \times 11 \mathrm{~cm} \text { to } \\
10 \mathrm{~cm} \times 28 \mathrm{~cm}\end{array}$ & $\begin{array}{c}13(100 \%) \text { primary } \\
\text { closure }\end{array}$ & Unspecified & $\begin{array}{c}1(7.7 \%) \text { total } \\
\text { flap loss, } \\
1(7.7 \%) \\
\text { seroma }\end{array}$ \\
\hline $\begin{array}{l}\text { Cheng and } \\
\text { Saint-Cyr }{ }^{[6]}\end{array}$ & 1 & 1 & 1 abdomen & $\begin{array}{c}30 \mathrm{~cm} \times \\
24 \mathrm{~cm}\end{array}$ & 1 burn & $\begin{array}{c}\text { Doppler and } \\
\text { CTA }\end{array}$ & $30 \mathrm{~cm} \times 17 \mathrm{~cm}$ & Primary closure & None & None \\
\hline $\begin{array}{l}\text { D'Arpa } \\
\text { et al. }{ }^{[7]}\end{array}$ & 85 & 13 & $\begin{array}{l}3 \text { back, } \\
10 \text { chest }\end{array}$ & Unspecified & $\begin{array}{c}8 \text { cancer, } \\
4 \mathrm{HE}, \\
1 \mathrm{PS}\end{array}$ & Unspecified & $\begin{array}{c}8 \mathrm{~cm} \times 3 \mathrm{~cm} \text { to } \\
23 \mathrm{~cm} \times 12.5 \mathrm{~cm}\end{array}$ & $\begin{array}{l}13(100 \%) \text { primary } \\
\text { closure }\end{array}$ & Unspecified & None \\
\hline Go et al. ${ }^{[8]}$ & 1 & 1 & 1 chest & $5 \mathrm{~cm} \times 4 \mathrm{~cm}$ & 1 cancer & Doppler & Unspecified & Primary closure & $1 \mathrm{RT}$ & Seroma \\
\hline Ono et al. ${ }^{[9]}$ & 16 & 9 & $\begin{array}{l}1 \text { back, } \\
8 \text { chest }\end{array}$ & Unspecified & $\begin{array}{c}1 \text { burn, } \\
7 \mathrm{~K} / \mathrm{S}, \\
1 \text { pilonidal }\end{array}$ & CTA & $\begin{array}{l}8 \mathrm{~cm} \times 3 \mathrm{~cm} \text { to } \\
18 \mathrm{~cm} \times 5 \mathrm{~cm}\end{array}$ & $\begin{array}{c}9(100 \%) \text { primary } \\
\text { closure }\end{array}$ & Unspecified & None \\
\hline Ang et $a{ }^{[10]}$ & 1 & 1 & 1 abdomen & Unspecified & 1 cancer & CTA & Unspecified & Primary closure & Unspecified & None \\
\hline Xu et al. ${ }^{[11]}$ & 7 & 7 & 6 back & Unspecified & $\begin{array}{l}1 \text { cancer, } \\
5 \text { PS }\end{array}$ & Doppler & $\begin{array}{c}12 \mathrm{~cm} \times 16 \mathrm{~cm} \text { to } \\
25 \mathrm{~cm} \times 30 \mathrm{~cm}\end{array}$ & $\begin{array}{c}7(100 \%) \text { primary } \\
\text { closure }\end{array}$ & Unspecified & $\begin{array}{c}1(14.3 \%) \\
\text { wound } \\
\text { breakdown }\end{array}$ \\
\hline $\begin{array}{l}\text { Zang } \\
\text { et al. }{ }^{[12]}\end{array}$ & 9 & 9 & $\begin{array}{l}1 \text { abdomen, } \\
4 \text { back, } \\
2 \text { chest }\end{array}$ & $\begin{array}{l}6 \mathrm{~cm} \times 6 \mathrm{~cm} \text { to } \\
30 \mathrm{~cm} \times 20 \mathrm{~cm}\end{array}$ & 7 cancer & Doppler & $\begin{array}{c}13 \mathrm{~cm} \times 6.5 \mathrm{~cm} \text { to } \\
28 \mathrm{~cm} \times 10 \mathrm{~cm}\end{array}$ & $\begin{array}{c}9(100 \%) \text { primary } \\
\text { closure }\end{array}$ & Unspecified & $\begin{array}{c}3(33.3 \%) \\
\text { partial flap } \\
\text { necrosis }\end{array}$ \\
\hline Oh et $a{ }^{[13]}$ & 11 & 11 & 11 back & Unspecified & $\begin{array}{c}10 \text { cancer, } \\
1 \text { PS }\end{array}$ & Doppler & Unspecified & $\begin{array}{c}11(100 \%) \text { primary } \\
\text { closure }\end{array}$ & 4 smokers & $\begin{array}{c}5(45.5 \%) \\
\text { TVC }\end{array}$ \\
\hline Yuet al. ${ }^{[14]}$ & 33 & 18 & $\begin{array}{l}3 \text { abdomen, } \\
6 \text { back, } \\
2 \text { chest }\end{array}$ & $\begin{array}{l}6 \mathrm{~cm} \times 6 \mathrm{~cm} \text { to } \\
30 \mathrm{~cm} \times 20 \mathrm{~cm}\end{array}$ & 11 cancer & Doppler & $\begin{array}{c}13 \mathrm{~cm} \times 6.5 \mathrm{~cm} \\
\text { to } 28 \mathrm{~cm} \times \\
11 \mathrm{~cm}\end{array}$ & $\begin{array}{c}17(94.4 \%) \\
\text { primary closure, } \\
1 \text { skin grafted }\end{array}$ & Unspecified & $\begin{array}{c}4(22.2 \%) \\
\text { partial flap } \\
\text { necrosis }\end{array}$ \\
\hline $\begin{array}{l}\text { Yuste } \\
\text { et al. }{ }^{[15]}\end{array}$ & 2 & 2 & 1 back & Unspecified & $1 \mathrm{MM}$ & Unspecified & Unspecified & $\begin{array}{l}\text { Local tissue } \\
\text { rearrangement }\end{array}$ & Unspecified & TVC \\
\hline $\begin{array}{l}\text { Schmidt } \\
\text { et } a l^{[16]}\end{array}$ & 1 & 1 & 1 back & Unspecified & $1 \mathrm{MM}$ & Unspecified & Unspecified & Primary closure & Unspecified & None \\
\hline Kim et al. ${ }^{[17]}$ & 1 & 1 & 1 chest & $10 \mathrm{~cm} \times 7 \mathrm{~cm}$ & $1 \mathrm{RT}$ & CTA & $16 \mathrm{~cm} \times 7 \mathrm{~cm}$ & Primary closure & $1 \mathrm{RT}$ & None \\
\hline $\begin{array}{l}\text { Brunetti } \\
\text { et } a l^{[18]}\end{array}$ & 20 & 9 & 9 back & $\begin{array}{c}4 \mathrm{~cm} \times 4 \mathrm{~cm} \text { to } \\
6 \mathrm{~cm} \times 8 \mathrm{~cm}\end{array}$ & 9 cancer & Doppler & $\begin{array}{c}4 \mathrm{~cm} \times 6 \mathrm{~cm} \text { to } 6 \\
\mathrm{~cm} \times 14 \mathrm{~cm}\end{array}$ & $\begin{array}{c}69(100 \%) \text { primary } \\
\text { closure }\end{array}$ & Unspecified & None \\
\hline $\begin{array}{l}\text { loannidis } \\
\text { et al. }{ }^{[19]}\end{array}$ & 14 & 9 & $\begin{array}{l}6 \text { back, } \\
3 \text { chest }\end{array}$ & Unspecified & 9 cancer & Doppler & $\begin{array}{l}11 \mathrm{~cm} \times 5 \mathrm{~cm} \text { to } \\
25 \mathrm{~cm} \times 15 \mathrm{~cm}\end{array}$ & $\begin{array}{c}9(100 \%) \text { primary } \\
\text { closure }\end{array}$ & Unspecified & $1(7.1 \%)$ TVC \\
\hline $\begin{array}{l}\text { Kneser } \\
\text { et al. }\end{array}$ & 10 & 2 & 2 back & Unspecified & 1 cancer & CLDS & $\begin{array}{l}14 \mathrm{~cm} \times 6 \mathrm{~cm} \text { to } \\
17 \mathrm{~cm} \times 8 \mathrm{~cm}\end{array}$ & $\begin{array}{c}2(100 \%) \text { primary } \\
\text { closure }\end{array}$ & Unspecified & None \\
\hline lida et $a l^{[21]}$ & 13 & 3 & 3 back & Unspecified & $\begin{array}{c}2 \text { wounds, } \\
1 \\
\text { unspecified }\end{array}$ & Unspecified & Unspecified & Unspecified & Unspecified & Unspecified \\
\hline $\begin{array}{l}\text { Gunnarsson } \\
\text { et al. }{ }^{[22]}\end{array}$ & 34 & 10 & 10 back & Unspecified & $\begin{array}{c}8 \text { cancer, } \\
1 \mathrm{~K} / \mathrm{S} \text {, } \\
1 \text { wound }\end{array}$ & $\begin{array}{l}\text { CDU and } \\
\text { dissection }\end{array}$ & $\begin{array}{c}6 \mathrm{~cm} \times 7 \mathrm{~cm} \text { to } 8 \\
\mathrm{~cm} \times 21 \mathrm{~cm}\end{array}$ & $\begin{array}{c}310(100 \%) \text { primary } \\
\text { closure }\end{array}$ & Unspecified & None \\
\hline $\begin{array}{l}\text { Baghaki } \\
\text { et al. }{ }^{[23]}\end{array}$ & 52 & 49 & $\begin{array}{l}8 \text { abdomen, } \\
16 \text { back, } \\
12 \text { chest }\end{array}$ & Unspecified & $\begin{array}{c}1 \text { burn, } \\
24 \text { cancer, } \\
2 \mathrm{HS}, \\
4 \mathrm{~K} / \mathrm{S}, \\
5 \text { wounds }\end{array}$ & Doppler & $\begin{array}{l}6 \mathrm{~cm} \times 9 \mathrm{~cm} \text { to } \\
14 \mathrm{~cm} \times 35 \mathrm{~cm}\end{array}$ & $\begin{array}{c}49(100 \%) \text { primary } \\
\text { closure }\end{array}$ & Unspecified & $\begin{array}{c}40(81.6 \%) \\
\text { TVC, } \\
1(2.0 \%) \\
\text { partial flap } \\
\text { necrosis }\end{array}$ \\
\hline Total & 365 & 190 & $\begin{array}{c}14 \text { abdomen, } \\
101 \text { back, } \\
50 \text { chest }\end{array}$ & $\begin{array}{l}2 \mathrm{~cm} \times 5 \mathrm{~cm} \\
\text { to } 30 \mathrm{~cm} \times \\
24 \mathrm{~cm} \text {, rest } \\
\text { unspecified }\end{array}$ & $\begin{array}{c}3 \text { burn, } \\
105 \text { cancer, } \\
4 \mathrm{HS}, \\
6 \mathrm{HE}, \\
12 \mathrm{~K} / \mathrm{S}, \\
2 \mathrm{MM}, \\
1 \text { pilonidal, } \\
2 \mathrm{PM}, \\
20 \mathrm{PS}, \\
2 \mathrm{RT}, \\
8 \text { wound }\end{array}$ & $\begin{array}{l}\text { Doppler, } \\
\text { CDU, } \\
\text { CLDS, } \\
\text { CTA, } \\
\text { dissection, } \\
\text { unspecified }\end{array}$ & $\begin{array}{l}4 \mathrm{~cm} \times 6 \mathrm{~cm} \text { to } \\
30 \mathrm{~cm} \times 17 \mathrm{~cm} \text {, } \\
\text { rest unspecified }\end{array}$ & $\begin{array}{l}183(96.3 \%) \\
\text { primary closure, } \\
2 \text { skin grafted, } \\
2 \text { local tissue } \\
\text { rearrangements, } \\
3 \text { unspecified }\end{array}$ & $\begin{array}{c}14 \text { smokers, } \\
6 \mathrm{RT} \text {, } \\
\text { rest } \\
\text { unspecified }\end{array}$ & $\begin{array}{c}12(6.3 \%) \\
\text { partial flap } \\
\text { necrosis, } \\
2(1.1 \%) \\
\text { seroma, } \\
1(0.5 \%) \\
\text { wound } \\
\text { breakdown, } \\
48(25.3 \%) \\
\text { TVC }\end{array}$ \\
\hline
\end{tabular}

CDU: color Doppler ultrasonography; CLDS: combined laser Doppler spectrophotometry; CTA: computed tomography angiography; HE: hardware exposure; HS: hidradenitis suppuritiva; K/S: keloid/scar; MM: myelomeningocele; PM: pseudomeningocele; PS: pressure sore; TVC: transient venous congestion; RT: radiotherapy 
to find that the highest rate of complication was with venous congestion but that no permanent flap loss was noted in any case. All cases of venous congestion identified were transient, whether they were managed expectantly or with some intervention (i.e. leeches, derotation of flap, etc.). The other complications were with much less frequency and reviewing the patient's risk factors, they did not seem to adversely affect the outcomes. Unfortunately, many series did not identify preoperative risk factors in patients and so drawing conclusions from this are limited in this review. In addition, of those that did specify the risks factors, the patient-specific data was often combined with flaps of other areas of the body and/or there was not enough detailed information provided to determine if the complications occurred in those with risks factors (i.e. transient venous congestion occurrence in relation to patients that smoked).

Interestingly, none of the etiologies for the defects mentioned in any of the studies were traumatic. This may be that trunk wounds are generally not as likely to be traumatic compared to lower extremity wounds. Anecdotally, traumatic wounds do raise some concern in the reconstruction of a wound using a propeller flap as the perforator may be captured in the zone of injury.

One of limitations of this study is that the search terms and search database is limited. One of the challenges of broadening this search would be to search for each propeller flap by a described name or technique (i.e. LICAP flap) as it relates to the trunk, which would be much more extensive of a search. However, this provides an opportunity for further delving into the literature and providing a larger review that may be more inclusive than the broader search terms listed as part of our study. Another notable limitation is that publication bias of positive findings with relation to propeller flap outcomes of the studies currently available.

Variability in design of propeller flaps of course depends upon the shape, size, depth, and location of the defect. In general, axes of the flaps designed should be based perpendicular or oblique on the trunk and in parallel in extremities ${ }^{[7,24]}$.

When identifying perforators for dissection, it is the authors' preferred method to do so via handheld Doppler ultrasound as well as visual inspection upon dissection. Ono et al. ${ }^{[25]}$ provided a recent publication in 2017 with an excellent overview with preoperative modalities to identify perforators. While CTA, MRA, and CDU have grown tremendously as modalities in addition to multi-detector row computed tomography, the authors find these modalities time consuming and costly in a climate of American healthcare costs that continue to rise. However, there is significant value in these modalities in the authors' opinions with respective to complex reconstruction or those of reoperative reconstructive fields. Some colleagues at our institution utilize these modalities routinely and so there remains no consensus nor compelling data in the literature to support use of these methods over handheld Doppler ultrasound or even dissection with direct visualization. Indeed, a palpable pulse of the perforator in question is always a reassuring finding and indicator of flap viability. In keeping dissection principles in mind, we try to adhere in line with the findings of Wong et al. ${ }^{[26]}$ in that a $3-\mathrm{cm}$ pedicle length dissection is attempted to be obtained when safe. This is particularly prudent when utilizing degrees of rotation beyond 90 degrees in propeller fashion, but is only done when skeletonization is deemed appropriate and safe.

As discussed in the Tokyo criteria of 2011, the perforator-based propeller flap can be rotated a maximum of 180 degrees for wound reconstruction ${ }^{[27]}$. This has to do with torsion and kinking of the pedicle, ultimately which can lead to flap compromise and loss. If flap compromise in the form of venous congestion develops, return to the operating room and releasing the flap from its inset position is of the first consideration. Following this, if the compromise is not addressed then the flap should be rotated back to the donor site and observed for improvement. Still if minimal or no improvement is noted, dissection of the flap to its pedicle should occur to ensure the vascular leash is not the complicating factor.

With respect to management of the donor site, the authors agree with the conclusion of D'Arpa et al. ${ }^{[7]}$ in the decision tree of when a perforator-based propeller flap is utilized for reconstruction. Specifically, if the donor site cannot be closed primarily, then a free flap reconstructive option is sought first that would lead to less to donor site morbidity and improved cosmesis. In other words, a perforator-based propeller flap may be designed as large as the defect dictates so long as the donor site may be closed primarily. As with all reconstructions in plastic surgery, each defect poses its own challenges and nuance that the plastic and reconstructive surgeon must take into consideration prior to surgical intervention.

In conclusion, propeller flaps are a viable reconstructive option for trunk wounds and should be in the armamentarium of plastic and reconstructive 
surgeons. Despite its broad applicability and use, little is published regarding propeller flap reconstruction in trunk wounds. More aggregate data is needed in order to further review, evaluate, and refine propeller flap techniques and results.

\section{DECLARATIONS}

\section{Authors' contributions} Inception of the study, study design, and written manuscript: S. Moshrefi, G.K. Lee

\section{Financial support and sponsorship None.}

\section{Conflicts of interest}

There are no conflicts of interest.

\section{Patient consent Not applicable.}

\section{Ethics approval Not applicable.}

\section{REFERENCES}

1. Kroll SS, Rosenfield L. Perforator-based flaps for low posterior midline defects. Plast Reconstr Surg 1988;81:561-6.

2. Koshima I, Soeda S. Inferior epigastric artery skin flaps without rectus abdominis muscle. Br J Plast Surg 1989;42:645-8.

3. Brunetti B, Tenna S, Poccia I, Persichetti P. Propeller flaps with reduced rotational angles: clinical experience on 40 consecutive reconstructions performed at different anatomical sites. Ann Plast Surg 2017;78:202-7.

4. Zang M, Guo L, Liu Y. Propeller medial arm flap: a plan "B" for reconstruction of radiation ulcer of the chest wall. $J$ Plast Reconstr Aesthet Surg 2014;67:1769-70.

5. Moon SH, Choi JY, Lee JH, Oh DY, Rhie JW, Ahn ST. Feasibility of a deepithelialized superior gluteal artery perforator propeller flap for various lumbosacral defects. Ann Plast Surg 2015;74:589-93.

6. Cheng A, Saint-Cyr M. Use of a pre-expanded "propeller" deep inferior epigastric perforator (DIEP) flap for a large abdominal wall defect. J Plast Reconstr Aesthet Surg 2013;66:851-4.

7. D’Arpa S, Cordova A, Pignatti M, Moschella F. Freestyle pedicled perforator flaps: safety, prevention of complications, and management based on 85 consecutive cases. Plast Reconstr Surg 2011;128:892-906.

8. Go JY, Lim SY, Mun GH, Bang SI, Oh KS, Pyon JK. Recycling delayed perforator flap: Deep inferior epigastric artery perforator-based propeller flap from a prior vertical rectus abdominis musculocutaneous flap. J Plast Reconstr Aesthet Surg 2011;64:1238-41

9. Ono S, Chung KC, Hayashi H, Ogawa R, Takami Y, Hyakusoku H. Application of multidetector-row computed tomography in propeller flap planning. Plast Reconstr Surg 2011;127:703-11.
10. Ang GG, Rozen WM, Chauhan A, Acosta R. The pedicled 'propeller'deep inferior epigastric perforator (DIEP) flap for a large abdominal wall defect. J Plast Reconstr Aesthet Surg 2011;64:133-5.

11. Xu Y, Hai H, Liang Z, Feng S, Wang C. Pedicled fasciocutaneous flap of multi-island design for large sacral defects. Clin Orthop Relat Res 2009;467:2135-41.

12. Zang M, Yu S, Xu L, Zhao Z, Zhu S, Ding Q, Liu Y. Intercostal artery perforator propeller flap for reconstruction of trunk defects following sarcoma resection. J Plast Reconstr Aesthet Surg 2015;68:822-9.

13. Oh TS, Hallock G, Hong JP. Freestyle propeller flaps to reconstruct defects of the posterior trunk: a simple approach to a difficult problem. Ann Plast Surg 2012;68:79-82.

14. Yu S, Zang M, Xu L, Zhao Z, Zhang X, Zhu S, Chen B, Ding Q, Liu Y. Perforator propeller flap for oncologic reconstruction of soft tissue defects in trunk and extremities. Ann Plast Surg 2016;77:456-63.

15. Yuste $\mathrm{V}$, Delgado J, Silva M, Rodrigo J, Albiñana F. The double gluteal myocutaneous propeller flap for the coverage of massive myelomingoceles. J Plast Reconstr Aesthet Surg 2014;67:737-8.

16. Schmidt VJ, Horch RE, Dragu A, Beier JP, Eyüpoglu IY, Hirsch A, Kneser U. Myocutaneous propeller flap based on the superior gluteal artery (SGA) for closure of large lumbosacral meningomyelocoele defects: a case report. J Plast Reconstr Aesthet Surg 2012;65:521-4

17. Kim DY, Kim HY, Han YS, Park JH. Chest wall reconstruction with a lateral thoracic artery perforator propeller flap for a radiation ulcer on the anterior chest. J Plast Reconstr Aesthet Surg 2013;66:134-6.

18. Brunetti B, Tenna S, Aveta A, Poccia I, Segreto F, Cerbone V, Persichetti P. Posterior trunk reconstruction with the dorsal intercostal artery perforator based flap: clinical experience on 20 consecutive oncological cases. Microsurgery 2016;36:546-51.

19. Ioannidis S, Spyropoulou GA, Sadigh P, Shih HS, Jeng SF. Pedicled free-style perforator flaps for trunk reconstruction: a reliable method. Plast Reconstr Surg 2015;135:602-9.

20. Kneser U, Beier JP, Schmitz M, Arkudas A, Dragu A, Schmidt VJ, Kremer T, Horch RE. Zonal perfusion patterns in pedicled free-style perforator flaps. J Plast Reconstr Aesthet Surg 2014;67:e9-17.

21. Iida T, Narushima M, Yoshimatsu H, Mihara M, Kikuchi K, Hara H, Yamamoto T, Araki J, Koshima I. Versatility of lateral cutaneous branches of intercostal vessels and nerves: anatomical study and clinical application. J Plast Reconstr Aesthet Surg 2013;66:1564-8.

22. Gunnarsson GL, Jackson IT, Westvik TS, Thomsen JB. The freestyle pedicle perforator flap: a new favorite for the reconstruction of moderate-sized defects of the torso and extremities. Eur J Plast Surg 2015;38:31-6

23. Baghaki S, Diyarbakirlioglu M, Sahin U, Kucuksucu MA, Turna A Baca B, Aydın Y. Extended locoregional use of intercostal artery perforator propeller flaps. Microsurgery 2017;37:293-9.

24. Saint-Cyr M, Wong C, Schaverien M, Mojallal A, Rohrich RJ. The perforasome theory: vascular anatomy and clinical implications. Plast Reconstr Surg 2009;124:1529-44.

25. Ono S, Hayashi H, Ohi H, Ogawa R. Imaging studies for preoperative planning of perforator flaps: an overview. Clin Plast Surg 2017;44:2130 .

26. Wong CH, Cui F, Tan BK, Liu Z, Lee HP, Lu C, Foo CL, Song C. Nonlinear finite element simulations to elucidate the determinants of perforator patency in propeller flaps. Ann Plast Surg 2007;59:672-8.

27. Pignatti M, Ogawa R, Hallock GG, Mateev M, Georgescu AV, Balakrishnan G, Ono S, Cubison TC, D’Arpa S, Koshima I, Hyakusoku H. The "Tokyo" consensus on propeller flaps. Plast Reconstr Surg 2011;127:716-22 